\title{
Characteristics of bricks used in the domes of some historic bath buildings
}

\author{
Elif Uğurlu Sağın*, Hasan Böke ${ }^{1}$ \\ Department of Architectural Restoration, İzmir Institute of Technology, Urla, İmir, Turkey
}

\section{A R T I C L E I N F O}

\section{Article history:}

Received 30 October 2012

Accepted 5 November 2012

Available online 18 February 2013

\section{Keywords:}

Historic brick

Composition

Firing temperature

Durability

Conservation

\begin{abstract}
A B S T R A C T
In this study, characteristics of bricks used in the domes of some historic bath buildings dated to 15th century in İzmir were determined in order to indicate the properties of repair bricks that will be used in the conservation works of the domes. For this purpose, their basic physical properties, elemental and mineralogical compositions, firing temperatures and microstructural properties were determined by using XRF, XRD, SEM-EDS and TGA analysis. Analysis results indicated that the bricks are of low density, high porosity and were produced from raw materials containing low amounts of calcium poor clays fired at low temperatures $\left(<900^{\circ} \mathrm{C}\right)$. They are mainly consisted of small pores with $r<5 \mu \mathrm{m}$ that make the bricks more susceptible to salt crystallization and freeze-thaw cycles. Although the bricks were fired at low temperatures and susceptible to salt crystallization and freeze thaw cycles, the structural systems of the domes remained without losing their integrity due to the moderate climatic conditions of İzmir. Repair bricks that will be used in the conservation works of the domes should be compatible with the original ones and produced from calcium poor clays by firing at low temperatures.
\end{abstract}

(c) 2013 Elsevier Masson SAS. All rights reserved.

\section{Introduction}

The materials used in the construction of Ottoman baths were stones, bricks and binding materials. Rubble and cut stones were the main materials of wall systems where bricks were generally used in superstructure components such as arches, vaults and domes. Binding materials used in the construction of both walls and domes were lime mortars. Interior and exterior surfaces of the domes were covered with brick-lime plasters called cocciopesto that prevented water penetration to the structure. In previous studies, characteristics of mortars, plasters and stones used in the construction of some historic bath buildings dated to 15th century in Izmir were determined [1-3]. In this study, raw materials and production technologies of bricks used in the domes of same buildings were determined.

Bricks are manufactured by first removing coarse stones from the natural clay source before mixing with water. The plastic mixture is then shaped, dried and heated at temperatures greater than $600^{\circ} \mathrm{C}$ [4]. Some changes occur in mineralogical, chemical and physical properties of raw materials of bricks during heating. Heating destroys the crystal structure of clay and pozzolanic amorphous substances like metakaolin are formed when the heating

\footnotetext{
* Corresponding author. Tel.: +90 23275070 29; fax: +90 2327507012 .

E-mail addresses: elifugurlu@iyte.edu.tr (E. Uğurlu Sağın), hasanboke@iyte.edu.tr(H. Böke).

${ }^{1}$ Tel.: +90 23275070 35; fax: +90 2327507012 .
}

temperature is between 450 and $800{ }^{\circ} \mathrm{C}$ depending on the type of clay mineral [5]. At temperatures over $800^{\circ} \mathrm{C}$, pozzolanic activities are lost and high temperature mineral phases such as mullite and cristobalite are formed [6]. For Ca-rich clays, gehlenite formed at $800^{\circ} \mathrm{C}$, diopsite formed at $850^{\circ} \mathrm{C}$, wollastonite formed at $1050^{\circ} \mathrm{C}$; and for Ca-poor clays, hematite formed at $850^{\circ} \mathrm{C}$ are important mineral phases formed at different heating temperatures [7].

Mineralogical transformations during heating result in changes in the pore structure of bricks $[4,8]$. At firing temperatures around $800^{\circ} \mathrm{C}$, in bricks produced from Ca-rich clays, calcite $\left(\mathrm{CaCO}_{3}\right)$ is decomposed and calcium oxide $(\mathrm{CaO})$ is formed. In the presence of water, calcium oxide returns into portlandite $\left(\mathrm{Ca}(\mathrm{OH})_{2}\right)$, and portlandite transforms into calcite again as a result of its reaction with $\mathrm{CO}_{2}$. These reactions generate a considerable increase in volume and formation of fissures that generally known as "lime blowing" in the brick structure $[4,8]$. For bricks produced from Ca-poor clays, porosity slightly reduces at this temperature. At firing temperatures below $900^{\circ} \mathrm{C}$, pores smaller than $1 \mu \mathrm{m}$ predominate in both types of bricks [4]. At firing temperatures around $900^{\circ} \mathrm{C}$, pore size distribution remains almost unchanged in Ca-rich bricks while the amount of pores bigger than $7 \mu \mathrm{m}$ significantly increase in Ca-poor bricks [4]. The most significant increment in the amount of larger pores and the lowest porosity is obtained at firing temperatures around $1000^{\circ} \mathrm{C}$ in $\mathrm{Ca}$-poor bricks and at firing temperatures around $1100^{\circ} \mathrm{C}$ in Ca-rich bricks [4].

Shaping method (molding, pressing, extrusion) used during manufacturing is another factor that affects the porosity of bricks [9]. But, to evaluate the effect of shaping method to porosity is 


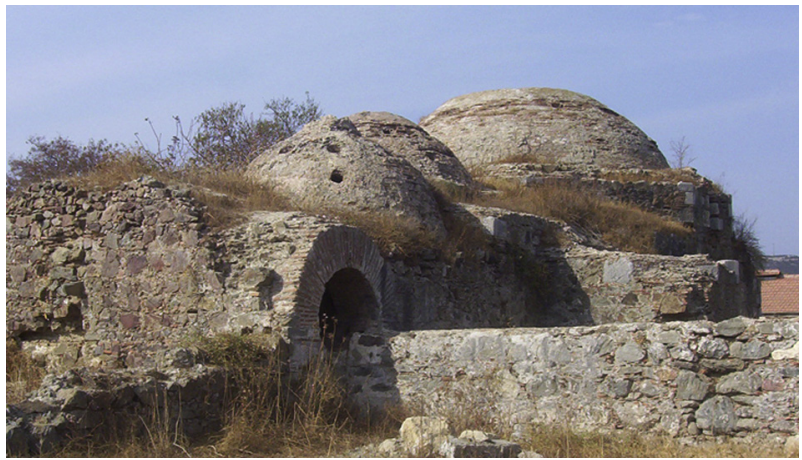

Fig. 1. Düzce Bath in Seferihisar-İzmir.

much more complicated since such some other factors such as firing temperature, firing speed also need to be taken into account [9].

Total porosity and pore sizes of bricks are important factors that affect the durability and mechanical resistance of bricks $[4,10]$. Bricks with high porosity and high amounts of small pores $(r<1 \mu \mathrm{m})$ are more susceptible to salt crystallization and freezethaw cycles $[4,10,11]$. Changes in porosity due to salt crystallization and freeze-thaw cycles reduce the mechanical resistance of bricks over time [4,12].

This study aims to determine the properties of bricks used in the domes of some historic bath buildings dated to 15th century in order to indicate the characteristics of repair bricks that will be used in the conservation works of domes.

\section{Experimental methods}

In this study, basic physical properties, mineralogical and chemical compositions, firing temperatures, microstructural properties and pozzolanic activities of bricks used in the domes of four Ottoman bath buildings, which are Hersekzade, Kamanlı, Düzce and Ulamıs baths located in İzmir, were investigated (Fig. 1).

Bulk density and porosity, which are the main physical properties of bricks, were determined by using standard test methods [13]. Mineralogical compositions were determined by X-ray diffraction analyses (Philips X-Pert Pro X-ray Diffractometer). Firing temperatures of bricks were determined in relation to their mineralogical compositions. Elemental compositions were identified by using X-ray fluorescence analyses (XRF) carried out on a Spectra IQ II spectrometer. Microstructures were determined by Philips XL 30S FEG Scanning Electron Microscope (SEM) coupled with X-Ray Energy Dispersive System (EDS). Weight losses between $200-600^{\circ} \mathrm{C}$ due to the loss of chemically bound waters and between 600 and $900^{\circ} \mathrm{C}$ due to the loss of $\mathrm{CO}_{2}$ during decomposition of calcium carbonate were determined by using Shimadzu TGA-21. The pozzolanic activity of the bricks was identified by measuring the differences in electrical conductivities $(\mathrm{mS} / \mathrm{cm}$ ) before and after the addition of powdered brick (less than $53 \mu \mathrm{m}$ ) into saturated calcium hydroxide solution [14].

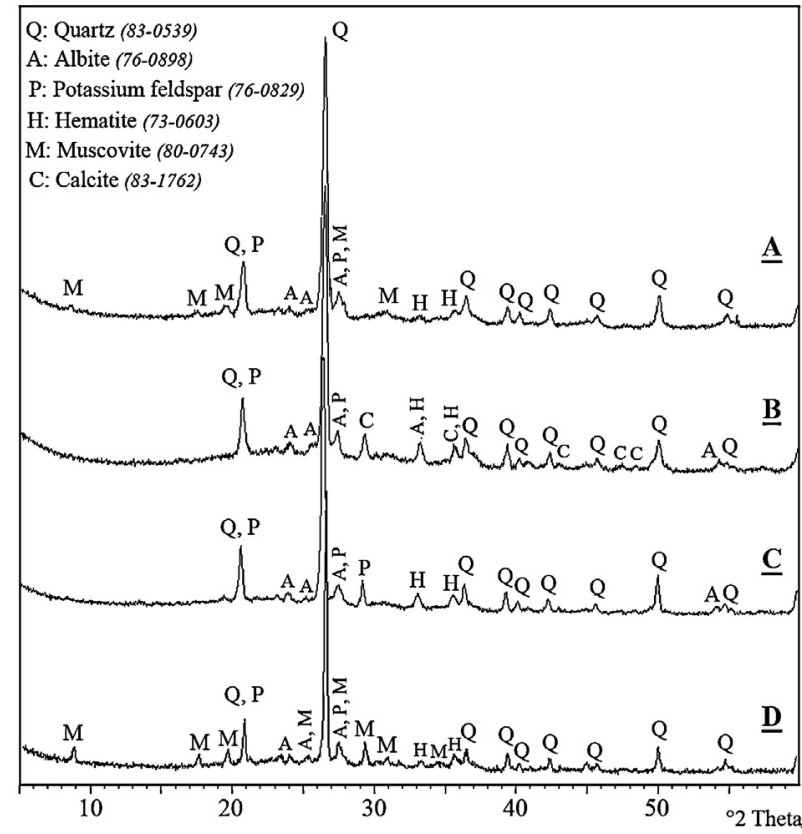

Fig. 2. XRD patterns of bath bricks (A: Hersekzade, B: Kamanlı, C: Düzce, D: Ulamış).

\section{Results and discussions}

\subsection{Basic physical properties}

All bricks are of low density and high porosity. Density and porosity values of bricks are between 1.7 and $1.8 \mathrm{~g} / \mathrm{cm}^{3}$ and 33 and $37 \%$, by volume, respectively. These values were almost in the same ranges with other bricks used in domes of some historic buildings in Anatolia [15]. The use of light bricks in the domes may be attributed to provide structural stability [16].

\subsection{Mineralogical and elemental compositions}

XRD analysis indicated that bricks are mainly composed of quartz $\left(\mathrm{SiO}_{2}\right)$, albite $\left(\mathrm{Na}\left(\mathrm{AlSi}_{3} \mathrm{O}_{8}\right)\right)$, potassium feldspar $\left(\mathrm{KAl}_{2} \mathrm{Si}_{2} \mathrm{O}_{5}(\mathrm{OH})_{4}\right)$ and muscovite $\left(\mathrm{KAl}_{2}\left(\mathrm{AlSiO}_{3} \mathrm{O}_{10}\right)(\mathrm{F}, \mathrm{OH})_{2}\right)$ (Fig. 2)

$\mathrm{XRF}$ analysis results revealed that bricks are composed of high amounts of $\mathrm{SiO}_{2}, \mathrm{Al}_{2} \mathrm{O}_{3}, \mathrm{Fe}_{2} \mathrm{O}_{3}$, and low amounts of $\mathrm{Na}_{2} \mathrm{O}, \mathrm{K}_{2} \mathrm{O}$, $\mathrm{MgO}$ and $\mathrm{CaO}$ (Table 1 ). The presence of low amounts of $\mathrm{Ca}$ in their composition reveals that calcium poor clay was used in the manufacturing of the bricks.

The bricks were found as non-pozzolanic according to the pozzolanic activity measurements carried out by measuring the differences in electrical conductivities $(\mathrm{mS} / \mathrm{cm})$ before and after addition of powdered bricks (less than $53 \mu \mathrm{m}$ ) into saturated calcium hydroxide solution [14]. In this method, bricks were accepted as pozzolanic if the difference between two measurements is bigger than $1.2 \mathrm{mS} / \mathrm{cm}$. Electrical conductivity differences of the examined bricks ranging from $0.2-0.7 \mathrm{mS} / \mathrm{cm}$ reveals that examined bricks are not pozzolanic. These results show that amount of clay

Table 1

Percent elemental composition of the bricks identified by XRF.

\begin{tabular}{|c|c|c|c|c|c|c|c|c|c|}
\hline Samples & $\mathrm{SiO}_{2}$ & $\mathrm{Al}_{2} \mathrm{O}_{3}$ & $\mathrm{Fe}_{2} \mathrm{O}_{3}$ & $\mathrm{MgO}$ & $\mathrm{CaO}$ & $\mathrm{Na}_{2} \mathrm{O}$ & $\mathrm{K}_{2} \mathrm{O}$ & $\mathrm{TiO}_{2}$ & $\mathrm{P}_{2} \mathrm{O}_{5}$ \\
\hline Her. & 62.66 & 18.81 & 6.34 & 2.19 & 1.01 & 0.32 & 2.72 & 0.84 & 0.04 \\
\hline Kam. & 65.07 & 15.77 & 6.27 & 1.73 & 3.08 & 0.39 & 2.54 & 0.66 & 0.06 \\
\hline Duz. & 69.09 & 15.12 & 6.87 & 1.65 & 0.57 & 0.31 & 1.96 & 0.71 & 0.08 \\
\hline Ula. & 59.87 & 18.72 & 6.97 & 2.55 & 2.34 & 0.32 & 3.09 & 0.80 & 0.14 \\
\hline
\end{tabular}

Her.: Hersekzade; Kam.: Kamanlı; Duz.: Düzce; Ula.: Ulamış. 


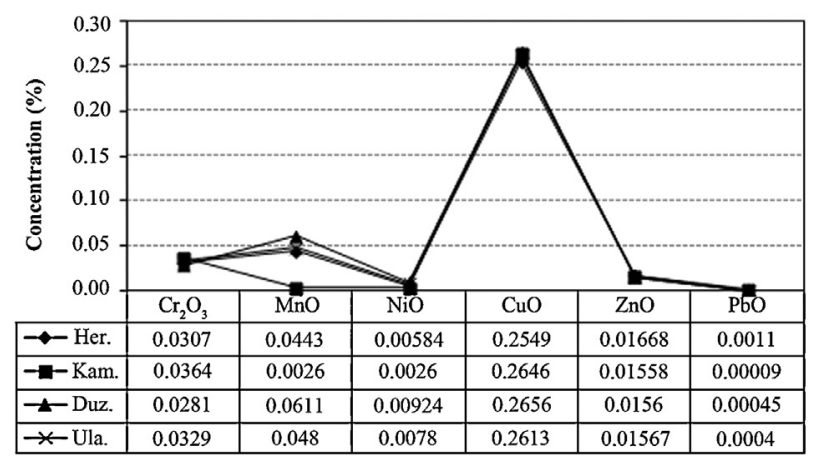

Fig. 3. Trace element compositions of the bricks identified by XRF.

minerals in bricks is not sufficient to produce pozzolanic amorphous substances $[17,18]$.

Trace elements compositions are accepted as peculiar characteristics to the geographical location and the source of raw materials and evaluated for this purpose in some archaeometric studies [7,19]. Trace elements compositions of the examined bricks are similar (Fig. 3). It may be possible to say that same raw material sources had been used in the production of the bricks according to these results.

\subsection{Firing temperatures}

Thermal analysis (TGA) was carried out in order to evaluate whether the firing of bricks was carried out until the clay minerals dehydroxylated and the bricks contain calcium carbonate. The negligible amounts of weight losses are observed in the ranges of $100-600^{\circ} \mathrm{C}$ and $600-900^{\circ} \mathrm{C}$ in the TGA graphs (Fig. 4). This indicates

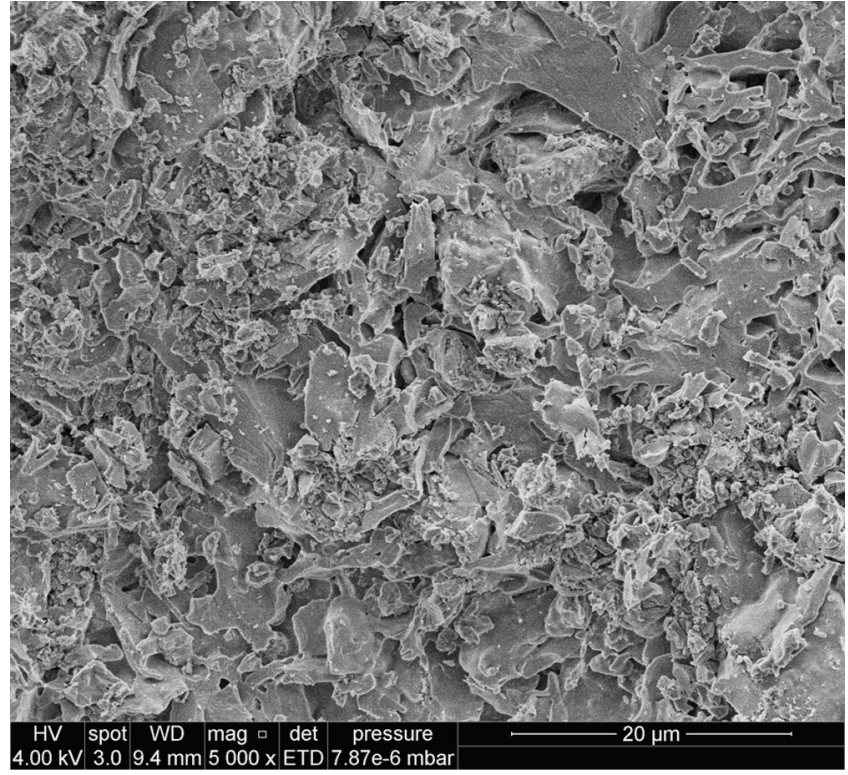

Fig. 5. SEM image of feldspar and quartz crystals in the brick matrices.

that raw materials of bricks were dehydroxylated during firing and they contain low amounts of calcite in their compositions.

Heating bricks at high temperatures $\left(>900^{\circ} \mathrm{C}\right)$ results in damage in their amorphous structures and leads to formation of high temperature products such as mullite, crystoballite [6]. Absence of high temperature products like mullite and cristobalite in the XRD diffraction patterns (Fig. 2) showed that firing temperatures did not exceed $950^{\circ} \mathrm{C}$. The existence of hematite revealed that bricks were heated at around $850^{\circ} \mathrm{C}[6]$.
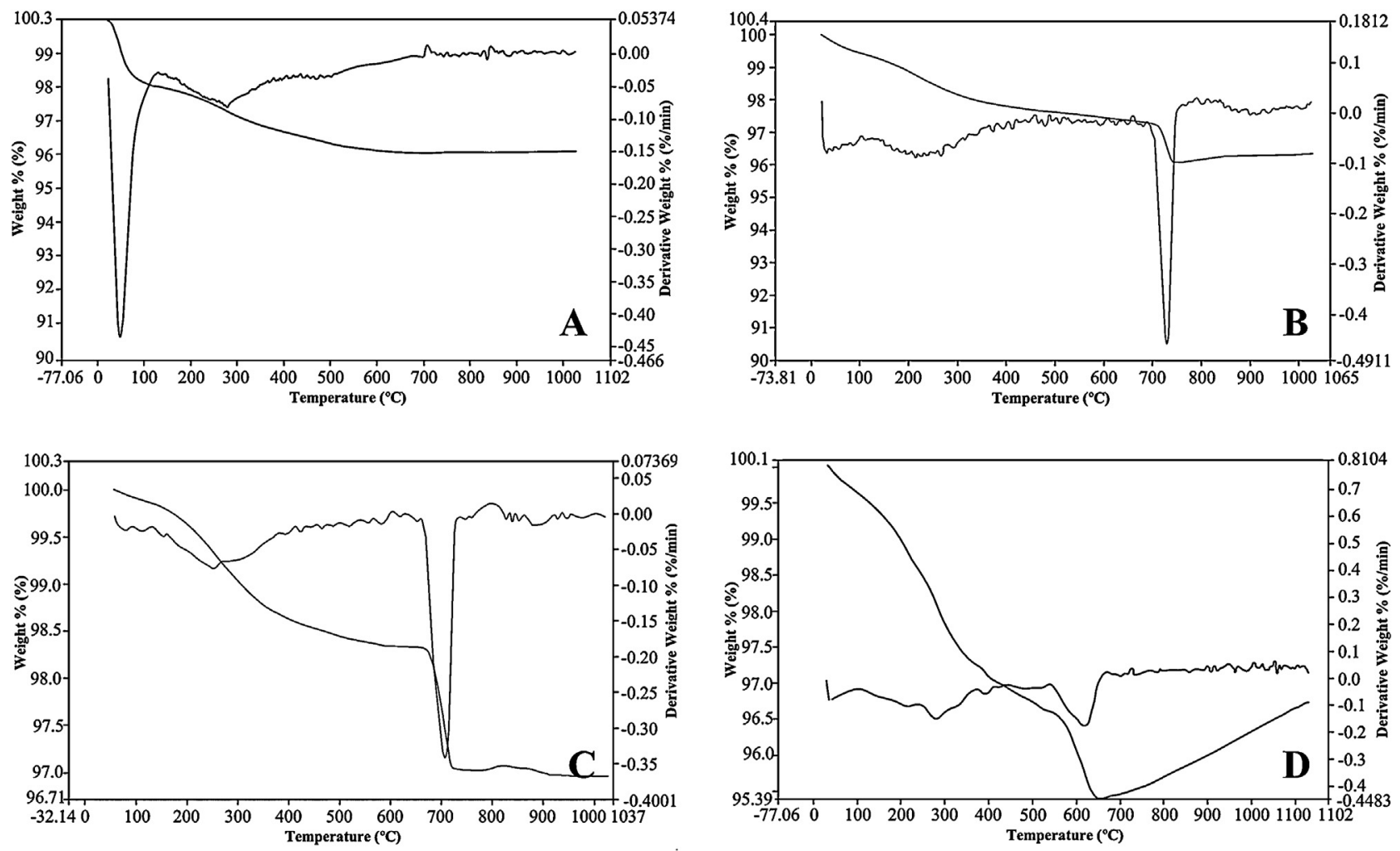

Fig. 4. TGA graphs of bath bricks (A: Hersekzade, B: Kamanlı, C: Düzce, D: Ulamış). 


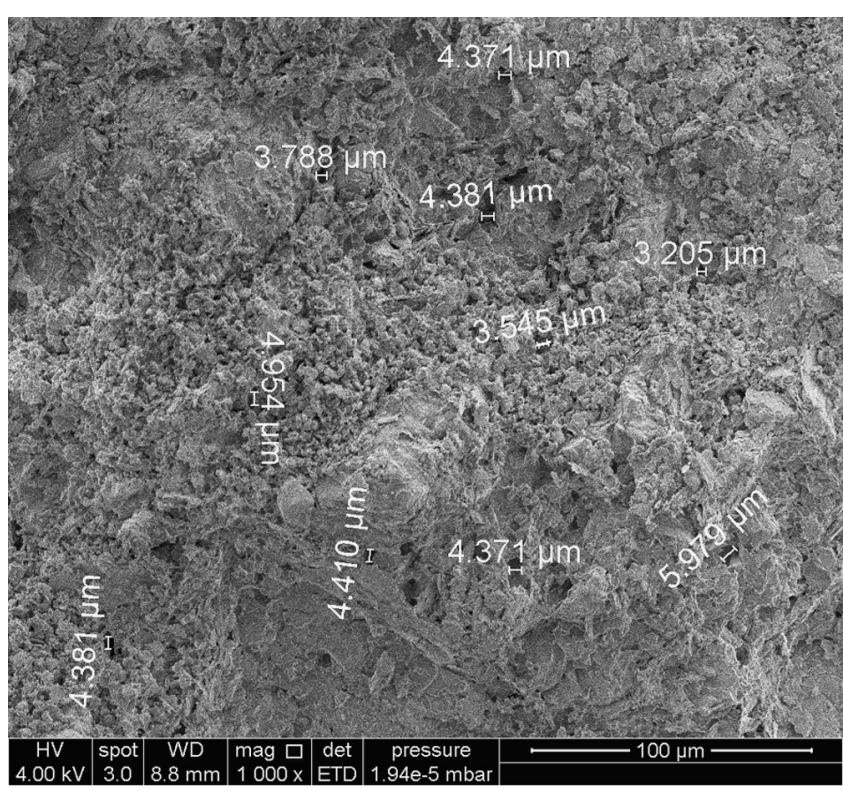

Fig. 6. SEM image showing the pore sizes in the brick matrices.

\subsection{Microstructural properties}

Microstructural characteristics were determined by SEM analysis. In the SEM images, 2-7 $\mu \mathrm{m}$ sized crystals of feldspar and quartz are observed in the bricks matrices (Fig. 5). Microstructural analysis indicated that the brick matrices are mostly composed of small pores $r<5 \mu \mathrm{m}$ (Fig. 6 ) that make the bricks more susceptible to salt crystallization and freeze-thaw cycles.

As mentioned before, between firing temperatures of 700 and $1000^{\circ} \mathrm{C}$, durability of bricks increase due to decrement in the amount of micropores and pore connectivity [4]. Although the bricks used in the domes of the investigated baths were fired at low temperatures and consisted of small pores, the structural systems of the baths remained without losing their integrity. This can be explained by moderate climatic conditions of İzmir [20] and by the use of brick-lime plasters (cocciopesto) which prevents water penetration to the building and also prevents evaporation through bricks [2].

\section{Conclusions}

Bricks used in the construction of the domes of the baths are low dense and high porous materials. They were produced from raw materials containing low amounts of Ca-poor clay and fired at low temperatures.

Although the bricks are more susceptible to salt crystallization and freeze-thaw cycles since they are mostly composed of small pores, the domes constructed by these bricks remain intact due to the climatic conditions of İmir and by the use of brick-lime plasters.

New bricks that will be used in the conservation works of domes should be compatible with the existing bricks. They must be produced by using Ca-poor clays, traditional production techniques and heating at low temperatures $\left(\sim 850^{\circ} \mathrm{C}\right)$.

\section{Acknowledgements}

The authors thank the researchers of the Centre for Materials Research at the İzmir Institute of Technology for XRF, XRD, SEM-EDS and TGA analyses during the experimental stage of this study.

\section{References}

[1] H. Böke, Ö. Çizer, B. İpekoğlu, E. Uğurlu, K. Şerifaki, G. Toprak, Characteristics of lime produced from limestone containing diatoms, Constr Build Mater 22 (2008) 866-874.

[2] E. Uğurlu, H. Böke, The use of brick-lime plasters and their relevance to climatic conditions of historic bath buildings, Constr Build Mater 23 (2009) 2442-2450.

[3] K. Reyhan, Construction techniques and materials of ottoman period baths in Urla-Seferihisar region, M. Sc. Thesis, İzmir Institute of Technology, Turkey, 2004.

[4] G. Cultrone, E. Sebastián, K. Elert, M. Jose de la Torre, O. Cazalla, C. RodriguezNavarro, Influence of mineralogy and firing temperature on the porosity of bricks, J Eur Ceram Soc 24/3 (2004) 547-564.

[5] C. He, B. Osbaeck, E. Makavicky, Pozzolanic reactions of six principal clay minerals: activation, reactivity assessments and technological effects, Cement Concrete Res 25/8 (1995) 1691-1702.

[6] L. Sujeong, Y.J. Kim, H.S. Moon, Phase transformation sequence from kaolinite to mullite investigated by an energy-filtering transmission electron, J Am Ceram Soc 10 (1999) 2841-2848.

[7] P. Cardiano, S. Ioppolo, C. De Stefano, A. Pettignano, S. Sergi, P. Piraino, Study and characterization of the ancient bricks of Monastery of "San Filippo di Fragalá" in Frazzanò (Sicily), Anal Chim Acta 519 (2004) 103-111.

[8] K. Elert, G. Cultrone, C. Rodriguez-Navarro, E. Sebastián Pardo, Durability of bricks used in the conservation of historic buildings - influence of composition and microstructure, J Cult Herit 4 (2003) 91-99.

[9] M.I. Carretero, M. Dondi, B. Fabbri, M. Raimondo, The influence of shaping and firing technology on ceramic properties of calcareous and non-calcerous illiticchloritic clays, Appl Clay Sci 20 (2002) 301-306.

[10] S.R. Mallidi, Application of mercury intrusion porosimetry on clay bricks to assess freeze-thaw durability. A bibliography with abstracts, Constr Build Mater 10 (6) (1996) 461-465.

[11] M. Maage, Frost resistance and pore size distribution in bricks, Mater Struct 17 (101) (1984) 345-350.

[12] S.I. Marras, I.A. Ihtiaris, N.K. Hatzitrifon, K. Sikalidis, E.C. Aifantis, A Preliminary study of stress-assisted penetration in ceramic bricks, J Eur Ceram Soc 20 (2000) 489-495.

[13] Commission 25 PEM RILEM, Tests defining the structure, Mater Constr 13 (1980) 177-181.

[14] M.P. Luxán, F. Madruga, J. Saavedra, Rapid evaluation of pozzolanic activity of natural products of conductivity measurement, Cement Concrete Res 19(1989) 63-68.

[15] S.S. Tunçoku, E.N. Caner-Saltık, H. Böke, Definition of the materials \& related problems of a XIIIth Century Anatolian Seljuk "Mescid": a case study in Konya city, in: M.J. Thiel (Ed.), Proceedings of the International RILEM-UNESCO congress: conservation of stone and other materials, Paris, June 29-July 1, SPON, London, 1993, pp. 368-375.

[16] E. Uğurlu Sağın, K. Reyhan, B. İpekoğlu, H. Böke, Investigation of construction techniques and material properties used in the domes of historical baths, in: Proceedings of WCCE-ECCE-TCCE Joint Conference 2 Seismic Protection of Cultural Heritage, Antalya, Turkey, October 31-November 1, Turkish Chamber of Civil Engineers, IMO publication, Ankara, 2011, pp. 249-259.

[17] G. Baronio, L. Binda, Study of the pozzolanicity of some bricks and clays, Constr Build Mater 11/1 (1997) 41-46.

[18] H. Böke, S. Akkurt, B. İpekoğlu, E. Uğurlu, Characteristics of brick used as aggregate in historic brick-lime mortars and plasters, Cement Concrete Res 36 (2006) 1115-1122.

[19] H. Mommsen, Provenance determination of pottery by trace element analysis: problems, solutions and applications, J Radioanal Nucl Ch 247/3 (2001) 657-662.

[20] B. İpekoğlu, H. Böke, Ö. Çizer, Assessment of material use in relation to climate in historical buildings, Build Environ 42 (2007) 970-978. 